\section{DETERMINATION OF THE COLLAPSE POTENTIAL OF SABKHA SOIL AND DUNE SAND ARID SURFACE SOIL DEPOSITS IN KUWAIT}

\author{
Fahad A. Al-Otaibia*, Humoud Melfi Aldaihanib
}

Article history

Received

12 April 2020

Received in revised form

15 February 2021

Accepted

30 March 2021

Published online

22 April 2021

aDepartment of Civil Engineering, College of Technological Studies (CTS), Public Authority for Applied Education and Training (PAAET), P.O. Box 92420, Shuwaikh Area, Kuwait

bCivil and Geo-Environmental Engineering, Implementation Construction Sector, Public Authority for Housing Welfare (PAHW), P.O. Box 92421, Shuhada Area, Kuwait

*Corresponding author fo.alotaibi@paaet.edu.kw

\section{Graphical abstract}

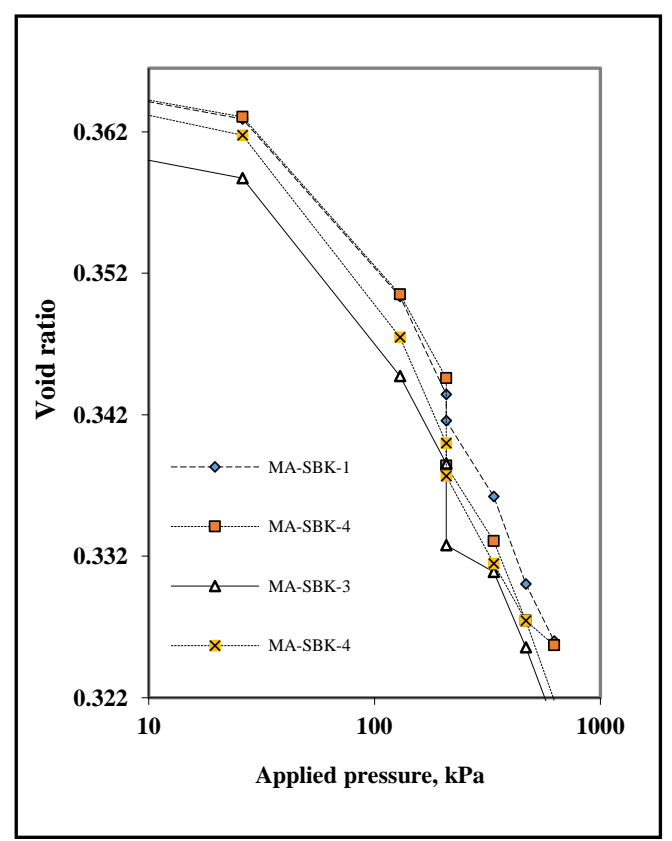

\begin{abstract}
Ensuring the sustainability of critical and limited natural soil resources is a major challenge in arid regions such as Kuwait. Investigations should be performed to identify and characterise collapsible surface soil deposits, and collapse potential should be assessed if possible in order to evaluate suitable stabilizing techniques. The cementation effect of different types of salts gives arid soils their considerable strength and stiffness in dry conditions. The collapse in these soils may occur due to the reduction of the chemical or physical bonds between the soil particles under wet conditions. Collapse Potential (CP) is an indication of the collapsibility of these soils. This paper presents the results of experimental work that was carried out to evaluate the collapse potential of two types of surface soil: sabkha soil and dune sand. The experimental program included physical and chemical soil characterization alongside a modified compaction test. The collapsibility of the soil at a stress of $200 \mathrm{kPa}$ was obtained by performing a Single Collapse Test (SCT) via a conventional odometer device in a temperature- and humidity-controlled environment. Collapse potential index tests were performed on the tested soil samples collected from eight locations in two study areas. The results suggest the problem severity is slight to none. However, the CP was higher for the sabkha soil samples than for the dune sand samples. The increase in collapsibility of the sabkha soil samples may be attributed to the removal of bonding between cementing particles upon wetting, leading to softening due to the rearrangement of soil particles.
\end{abstract}

Keywords: Sabkha soil, dune sands, collapse potential (CP), Single Collapse Test (SCT), Oedometer 


\subsection{INTRODUCTION}

As Kuwait is located in the north of the Arabian Peninsula's hot arid desert zone, it has a dry and arid climate with temperatures ranging from $3^{\circ} \mathrm{C}-15^{\circ} \mathrm{C}$ in winter and $25^{\circ} \mathrm{C}-45^{\circ} \mathrm{C}$ in summer. As noted by [1], the mean annual rainfall is approximately $105 \mathrm{~mm}$, with November and May experiencing the most rains. Flowing predominantly from the northwest, the winds tend to be dust-ridden and followed by rain and thunderstorms during March and April (Figure 1) [2].

Kuwait's desert plains are flat and gently undulating [3]. The following major groups are part of its surface deposits: aeolian, playa, residual, desert plain, alluvial fine sand, coastal deposits, and slope deposits [4]. Moreover, windblown dune sand covers some areas of northeast Kuwait, which is uniform soil that has high permeability. The surface windblown dune sands are easily influenced by saturation $[5,6]$ and are described as poorly graded soil that has high permeability [7], [8] and [9]. Sabkha flats are a major part of northern and southern coastal deposits. Sabkha, an Arabic term, refers to the large, flat, saltencrusted terrain that is deposited in arid conditions and is made up of clays, sand, silts, and salty mixtures [10].

Kuwait's low rainfall and high temperatures have led to extremely high evaporation potential that surpasses precipitation by a 30:1 ratio [2]. This has resulted in the saline ground water's upward movement [11] and an increased concentration of soluble material at or near the ground surface, which then leads to the formation of a cemented crust on the latter [12] as well as the formation of collapsible soils. Gypsum, chlorides, and carbonates form the major precipitated salts that function as cementing agents [13], [14], and [15]. Furthermore, previous cementing agents remain in the surface soil layer, which adds to the occurrences of soil collapse [16], [17], [18], [19] and [20]. As stated by [19], most natural collapsible soils are primarily wind-deposited sand and/or silts, including loess, volcanic dust deposits, and eolic beaches.

Collapsible soils' are any unsaturated soils whose particles are drastically rearranged accompanied by significant loss of volume when they are wetted, with or without additional loading [5], [8] and [21].

Kuwait's collapsible surface soil deposits mean it is necessary to carefully consider and assess the characteristics and properties of collapsible soils. Saturation impacts Kuwait's surface windblown dune sands and sabkha soils, and ground wetting can also result in their collapse [6] and [13]. Although the sabkhas have low compressibility, test findings suggest that there is high collapsibility for these arid, saline soils. This is mainly because of the dissolution of sodium chlorides, soil grain adjustment, and leaching of calcium ions [13], [14] and [15]. In most cases, the collapsibility process is either instantaneous or shortlived [22]. Collapse behavior causes significant distress as well as damage to man-made structures [23].
Several researchers observed that the construction industry's lack of knowledge concerning the identification, treatment, and behavior of the collapsing soils has resulted in several cases of foundation problems [24], [25], [26] and [27]. Though several studies have focused on the geotechnical properties of various surface soil deposits in Kuwait and the surrounding region, the geotechnical behavior and the differences in their chemical composition indicates the need for further research in this field to improve our understanding of the behavior of these soils in different conditions. Several researchers have evaluated collapse potential using experimental procedures, including single oedometer tests by [28] and double oedometer tests by [29]. Single oedometer tests are used extensively to assess the collapse potential, which can help in measuring soil collapse settlement. When a small quantity of clay and/or $\mathrm{CaCO} 3$ functions as the cementing agent, inundation in oedometer is sufficient to measure the collapse potential [27].

The method outlined above can be used for soils whose matrix has a low percentage of soluble minerals. However, with soils which contain high concentrations of soluble minerals or salts, the conventional inundation of the oedometer's soil specimen may result in the collapse potential being underestimated. This is because the amount of water may be insufficient for dissolving the present salts, making the water 'salt saturated' [27].

This paper will evaluate or quantify the collapse potential of Kuwait's two primary surface soil deposit types, including sabkha and dune sands. This paper seeks to address the problematic nature of these soils to gain a fundamental understanding of their geotechnical and engineering properties.

An oedometer test can help identify the collapse potential after inundation with water at a $200 \mathrm{kPa}$ stress. This test was conducted as per the procedure proposed by [30] and further described by [12].

\subsection{METHODOLOGY}

\subsection{Material Used}

The sampling areas selected for this paper are located in southern Kuwait, and represent the two major types of surface deposit. The first sampling location was Mina Abdullah, which is $60 \mathrm{~km}$ to the south of Kuwait City and includes the southern sabkha soil flats. The second sampling location was $80 \mathrm{~km}$ to the south of Kuwait City, and includes dune sand accumulations in Al-Wafra Area. Figure 1 shows the two selected sites.

To ensure that the salt-bearing soils were not affected, the disturbed soil samples that were collected were oven-dried for three days in the laboratory at a maximum temperature of $60^{\circ} \mathrm{C}$ [6], [13] and] [31]. First, the soil particles were gently crushed and then screened using a $4.75 \mathrm{~mm}$ sieve. The 
sieved materials were mixed rigorously, homogenized, and then used to identify the soil index properties.

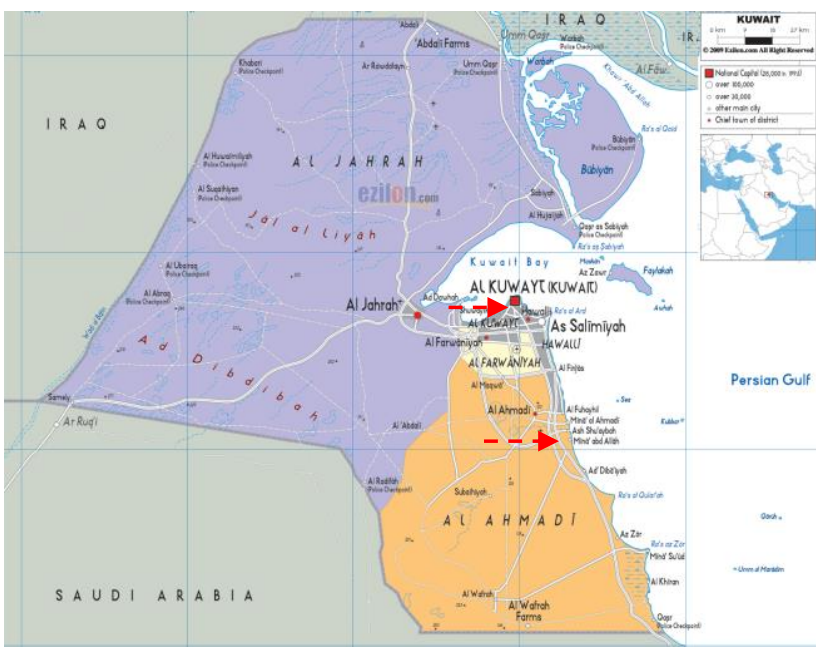

Figure 1 Sampling location map [30]

\subsection{Laboratory Program}

The engineering characteristics of the tested soil samples were then measured via a variety of laboratory tests. These included mechanical sieve, liquid limit, hydrometer analyses, plastic limit, compaction, collapse, and chemical tests.

\subsubsection{Index Properties}

To classify the soil samples as per the unified soil classification system (USCS), tests concerning grain size distribution and Atterberg limits were conducted [31]. Because only the collected sabkha soil sample included a substantial quantity of fines, mechanical sieve as well as hydrometer analyses were conducted as per [32], while mechanical sieve analysis alone was used to examine the dune sand soil samples. Particle size distribution D10, D30, D60, the coefficient of curvature (CC), and the uniformity coefficient (Cu) were identified.

The plastic and liquid limits tests were conducted for sabkha soil samples as per the [33]. Following this, these two values were used to calculate the plasticity index (PI).

A pycnometer was used as per [34] to determine the specific gravity (Gs) or particle density of different soil samples, while values were assessed considering the average of the two tests. Furthermore, as per [35], Modified Proctor compaction tests were conducted to obtain the compaction characteristics, including the maximum dry density (MDD) and optimum moisture content (OMC) for the dune and sabkha sand soil samples. Because of this study's limited budget, chemical characterization tests were conducted on only two samples from each location.

\subsubsection{Collapse Tests}

Standard front-loading oedometer tests were performed on the tested soil samples in order to characterise their collapse potential, as per the standard [37] proposed by [38].

This test included a soil specimen being placed in a stainless-steel ring $70 \mathrm{~mm}$ in diameter and $20 \mathrm{~mm}$ in height, and compacting it to its maximum dry density. Silicone gel was used to lubricate the inside of the ring and decrease the ring's side friction with the soil specimen. The stainless-steel ring's compacted sample was then placed between two porous stones. These two stones were saturated by keeping them in distilled water for 24 hours, which would also help in avoiding water absorption from the sample. The specimen was then kept in the consolidation, following which the seating pressure was applied and the load doubled when there was asymptotic monitored dial gauge reading against time. The sample was loaded to a $200 \mathrm{kPa}$ stress and then bombarded with distilled water for 24 hours. Next, calibrated dial gauges were used to calculate additional vertical displacements. The collapse problem severity was classified by the [35], adopting a $200 \mathrm{KPa}$ stress level. Another loading cycle was then applied, and the test was completed.

Each data point represents the average of the two tests performed to check the repeatability of the data.

\subsection{RESULTS AND DISCUSSION}

\subsection{Chemical Analysis}

The chemical compositions of the tested sabkha and dune sand soil samples are shown in Tables 1 and 2 respectively. The main component of the Sabkha soil samples is silicon dioxide, with an average value of $32.86 \%$. The second major component is calcium oxide at a $30.50 \%$ average value, followed by sulphate at $19.68 \%$. In the dune soil samples, the major component is silicon dioxide at an $86 \%$ average, and its other components of predominantly aluminium oxide and calcium oxide are at lower percentages. The $\mathrm{pH}$ values of the soils suggest that the tested soil samples have moderate to strong alkaline, with the sabkha soil samples having higher $\mathrm{pH}$ values. This may be because of the substantial quantities of carbonates found in the samples.

The findings of this study are similar to those of other studies on sabkha soils in southern Kuwait [36], [37], [38] and [39] as well as on dune sands [7], [8] and [12]. 
Table 1 Chemical characteristics of sabkha soil samples

\begin{tabular}{|c|c|c|c|c|c|c|c|c|c|c|}
\hline \multirow[t]{2}{*}{$\begin{array}{l}\check{o} \\
\stackrel{\varrho}{\bar{\omega}} \\
\frac{0}{3} \\
\frac{0}{D}\end{array}$} & 호 & 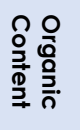 & $\cong$ & ̊̊̊ & 3 & 㞧 & $\underset{\omega}{\stackrel{D}{0}}$ & ত్ర & $\begin{array}{l}z \\
\text { o } \\
\text { ô }\end{array}$ & ఝ్ \\
\hline & & \multicolumn{9}{|c|}{$\%$} \\
\hline Sbk-1 & 8.2 & 1.75 & 34.39 & 28.95 & 2.13 & 1.76 & 4.51 & 0.97 & 1.24 & 18.95 \\
\hline Sbk-2 & 8.15 & 2.05 & 29.38 & 29.65 & 1.95 & 1.79 & 4.83 & 0.99 & 1.51 & 21.95 \\
\hline Sbk-3 & 8.18 & 1.96 & 34.3 & 32.38 & 1.86 & 1.52 & 3.69 & 0.81 & 0.89 & 18.78 \\
\hline Sbk-4 & 8.25 & 1.25 & 35.86 & 31.99 & 2.68 & 1.95 & 2.96 & 0.91 & 1.26 & 19.55 \\
\hline
\end{tabular}

Table 2 Chemical characteristics of dune sand soil samples

\begin{tabular}{|c|c|c|c|c|c|c|c|c|c|c|}
\hline \multirow[t]{2}{*}{$\begin{array}{l}\widetilde{\varrho} \\
\underline{\underline{\omega}} \\
\frac{0}{3} \\
\frac{0}{D}\end{array}$} & 후 & 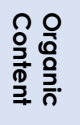 & ֻొ & ̊̊ & 3 & $\underset{\omega}{\stackrel{\mathbb{N}}{\mathbf{D}}}$ & 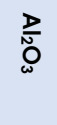 & గ్ర & $\begin{array}{l}z \\
\text { o } \\
0\end{array}$ & ఝ్ \\
\hline & & \multicolumn{9}{|c|}{$\%$} \\
\hline Dns-1 & 7.9 & 0.55 & 86.05 & 2.2 & 1.2 & 0.85 & 5.15 & 0.85 & 0.95 & 0.855 \\
\hline Dns-2 & $\begin{array}{l}7.9 \\
5\end{array}$ & 0.75 & 87.15 & 2.95 & 1.1 & 0.65 & 3.85 & 0.85 & 0.65 & 0.25 \\
\hline Dns-3 & 8.1 & 0.65 & 87.25 & 2.65 & 0.95 & 0.47 & 4.74 & 0.85 & 0.75 & 0.55 \\
\hline Dns-4 & 8.0 & 0.55 & 86.95 & 2.2 & 1.07 & 0.55 & 4.25 & 0.85 & 0.93 & 0.45 \\
\hline
\end{tabular}

\subsection{Physical Soil Properties}

The grain-size distribution curves for the sabkha samples, as illustrated in Figure 2, suggest that the fines passing No. 200 sieve varied from $10-18 \%$, and that the collected sabkha samples consisted of sand and no gravel. Further, the dune sand soil samples, as seen in Figure 2, were uniform medium-to-fine sands and contained less than $3 \%$ fines. Table 2 shows the tested soil samples' soil gradation analysis:

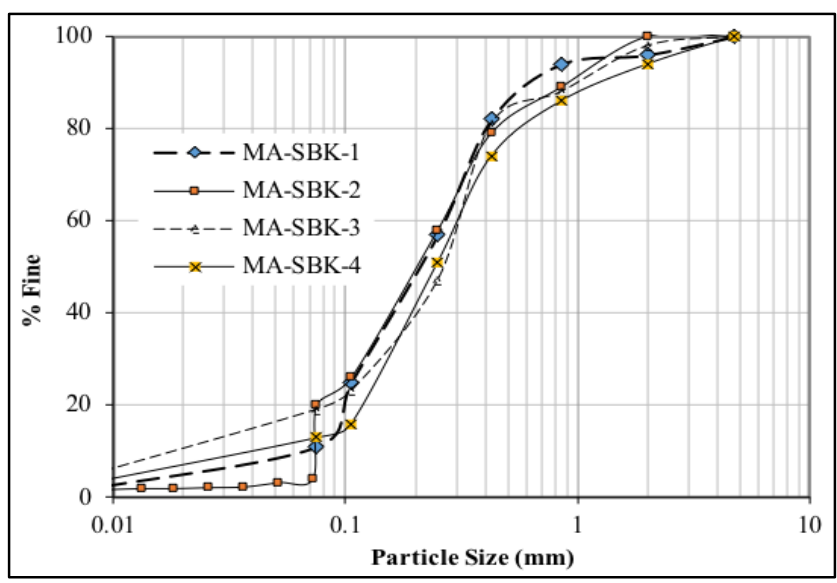

Figure 2 Grain size distribution curves for Mina Abdulla sabkha soil (MA-SBK)

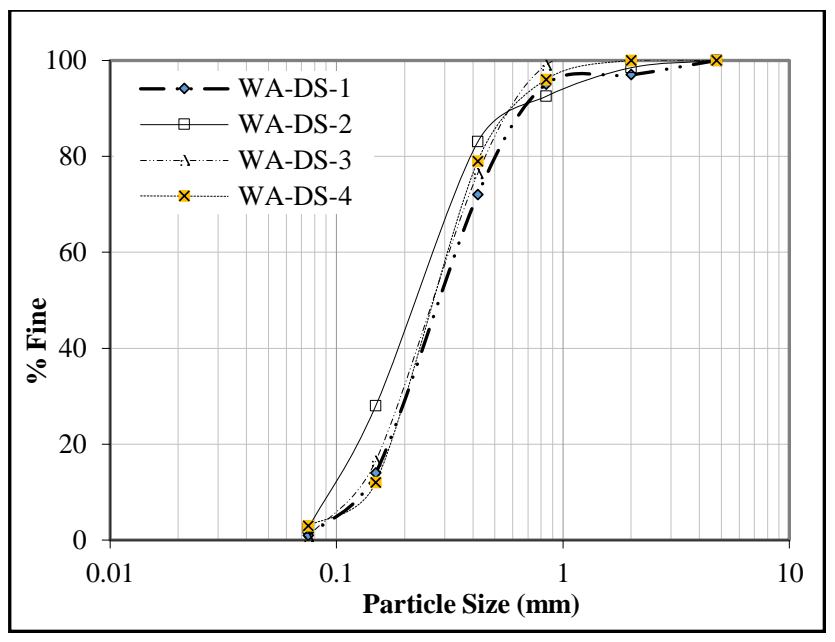

Figure 3 Grain size distribution curves for Al-Wafra dune sand (WA-DS)

Table 3 Physical characteristics of tested soil samples

\begin{tabular}{|c|c|c|c|c|c|c|c|c|c|c|c|c|c|}
\hline 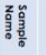 & 010 & 030 & 060 & $c_{v}$ & cc & FNE $\%$ & $\mathrm{Pl} \%$ & แ\% & ค\% & usc & GS & OMC \% & $\begin{array}{l}\text { MDD } \\
\mathrm{g} / \mathrm{cm}^{\prime}\end{array}$ \\
\hline 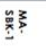 & 0.065 & 0.125 & 0.28 & 4.3 & 0.9 & 11.0 & 18.0 & 21.5 & 3.5 & SP.SM & . & 12.30 & 1930 \\
\hline 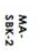 & 0.017 & 0.125 & 0.28 & 16.5 & 3.3 & 20.0 & 17.0 & 19.5 & 2.5 & SP.SM & & 9.95 & 1945 \\
\hline 䓂产 & 0.018 & 0.14 & 0.3 & 16.7 & 3.6 & 18.0 & 19.5 & 22.5 & 3.0 & SP.SM & 2.79 & 12.65 & 1907 \\
\hline 融产 & 0.038 & 0.16 & 0.3 & 7.9 & 2.2 & 120 & 14.5 & 16.5 & 2.0 & SP.SM & $\cdot$ & 9.35 & 1927 \\
\hline 能 & 0.14 & 0.21 & 0.35 & 2.5 & 0.9 & 1.0 & & $\mathrm{NP}$ & NP & $S P$ & & 11.20 & 1700 \\
\hline 隹. & 0.095 & 0.17 & 0.275 & 2.9 & 1.1 & 2.5 & & $\mathrm{NP}$ & NP & SP & 2.75 & 12.55 & 1718 \\
\hline 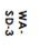 & 0.13 & 0.18 & 0.31 & 2.4 & 0.8 & 0.8 & & $\mathrm{NP}$ & NP & SP & & 11.50 & 1680 \\
\hline 蹵 & 0.15 & 0.2 & 0.32 & 2.1 & 0.8 & 3.0 & & $N P$ & NP & SP & & 9,35 & 1683 \\
\hline
\end{tabular}

The results of the soil gradation are similar to the results noted by [36], [37] as well as [39] regarding southern Kuwait's sabkha soils, along with the findings of [7], [8], [12] and [40] regarding dune sands.

The consistency limits values, as presented in Table 1 , indicate that sabkha and dune soil samples were low-plastic and non-plastic, respectively. The sabkha soil's low plasticity is considered to be a result of its low fine contents and low clay particle count.

According to the Unified Soil Classification System (USCS), the sabkha sand soil samples are regarded as poorly graded silty sand (SP-SM), while the dune sand soil samples are poorly graded sand (SP). The results of the soil classification tests are similar to the findings of other studies investigating soils from Kuwait and the Gulf region, such as those by [37], [38], [39], and [39].

The specific gravity values of the sabkha and dune sand soil samples were 2.65 and 2.8 respectively. The specific gravity values of the sabkha soils are lower than the specific gravity values of typical or silty sands. This is supposed to be caused by the combined impact of the specific gravity's low oven temperature $\left(60^{\circ} \mathrm{C}\right)$ and the high salt content of the sabkha soils [41]. 


\subsection{Compaction Characteristics}

Figures 4 and 5 illustrate the findings from the modified Proctor compaction tests regarding the selected sabkha and dune sand soil samples. They demonstrate that there are defined peaks in the compaction curves from the sabkha soil samples, and double peaks in the flatter compaction curves of the dune sand soil samples. Table 3 presents the optimum moisture content (OMC) as well as maximum dry density (MDD) values.

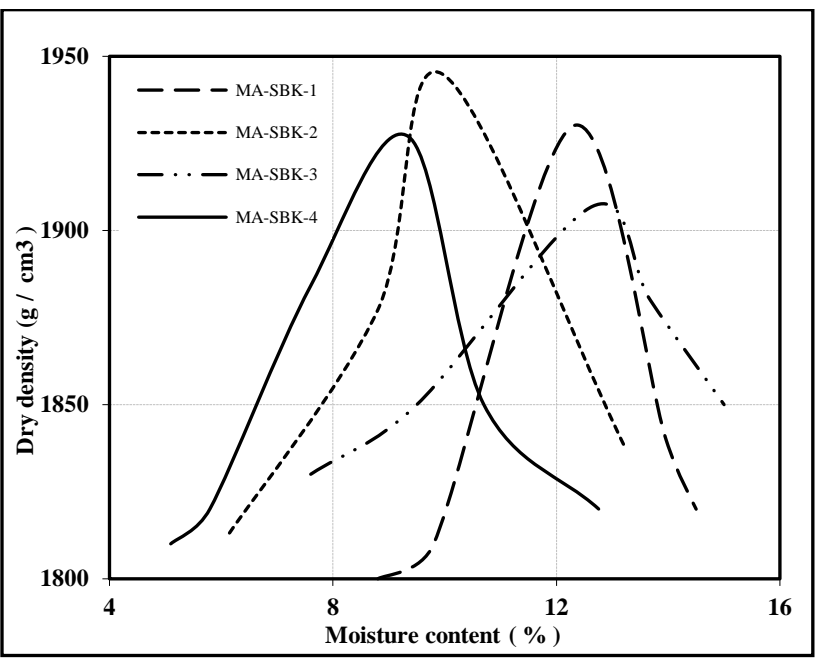

Figure 4 Dry density versus moisture content for Mina Abdulla sabkha soil (MA-SBK)

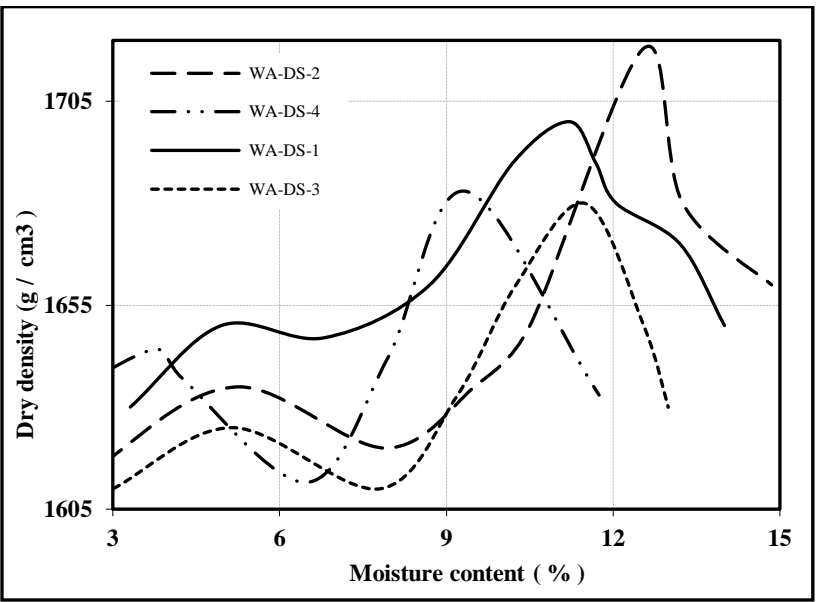

Figure 5 Dry density versus moisture content for Al-Wafra dune sand (WA-DS)

The sabkha soil has higher dry density values than the dune sand samples because of the cementation effect of the sabkha soil particles, while the compacted dune soil's higher void may be caused by its lower fines content. The MDD and OMC values observed in this study are similar to the findings of other studies concerning sabkha soils in Kuwait and the Gulf region, such as those by [38] and [39].

\subsection{Collapse Potential Test}

This test's primary aim is to assess the collapse potential of both the sabkha and dune sand soil samples, which is the collapse strain at a $200 \mathrm{KPa}$ applied pressure [25].

Figures 6 and 7 illustrate a collapse test's e-log $p$ relationship concerning the sabkha and dune sand soil samples respectively, regarding a $200 \mathrm{kPa}$ normal pressure. The $200 \mathrm{kPa}$ loading mark's vertical line indicates the sudden compression followed by inundation. The vertical line's length under a $200 \mathrm{kPa}$ normal pressure refers to the measure of the soil's collapsibility, as presented in Figures 8 and 9 for the sabkha and dune sand soil samples. The figures show that the $200 \mathrm{kPa}$ reading mark's vertical line is longer for the sabkha soil samples than for the dune sand soil samples.

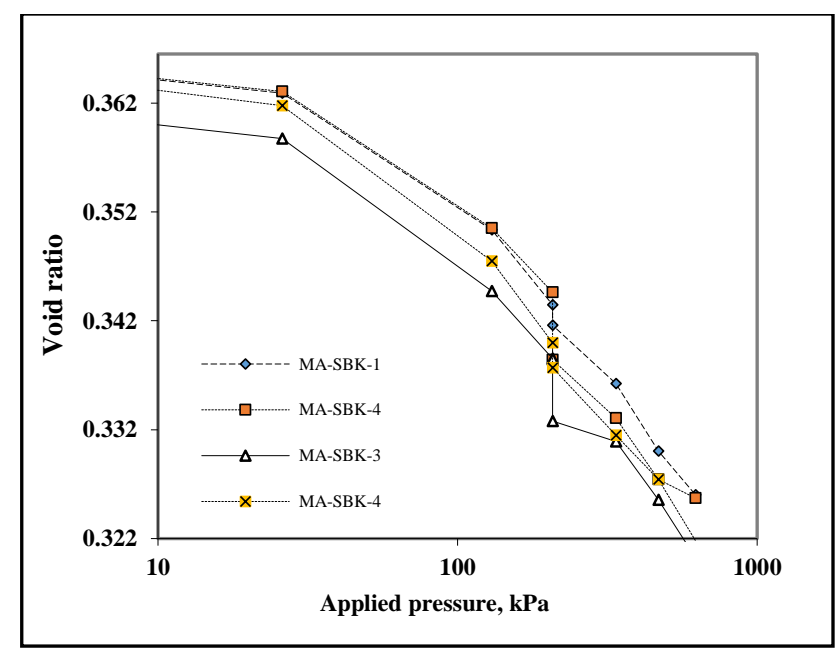

Figure 6 Collapse test results for Mina Abdulla sabkha soil (MA-SBK)

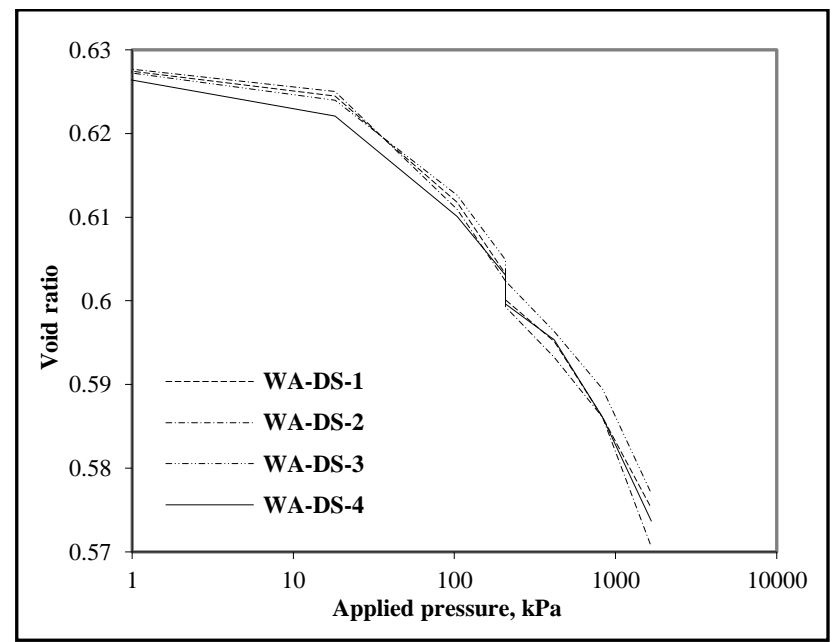

Figure 7 Collapse test results for Al-Wafra dune sand (WA-DS) 


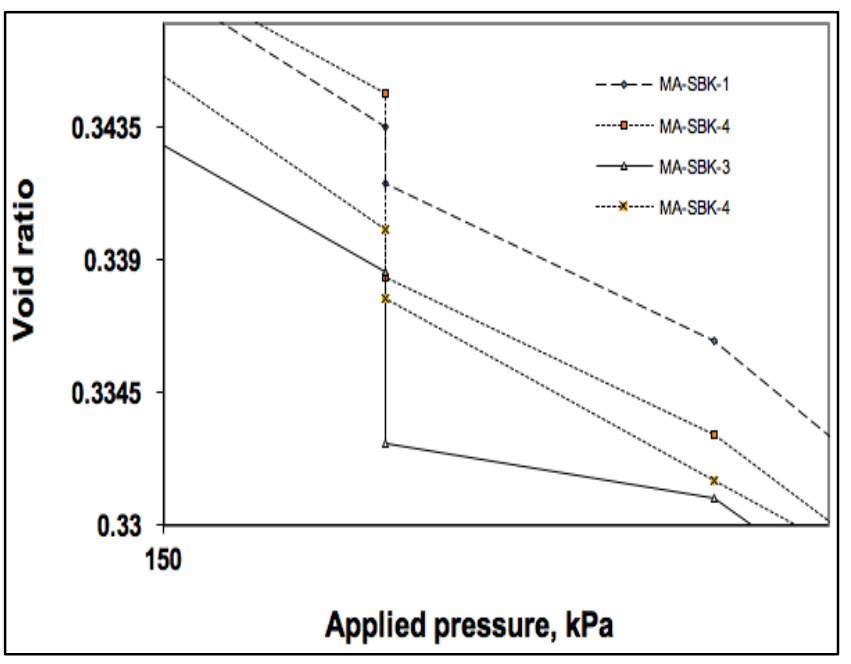

Figure 8 Collapse test results for Mina Abdulla sabkha soil (MA-SBK)

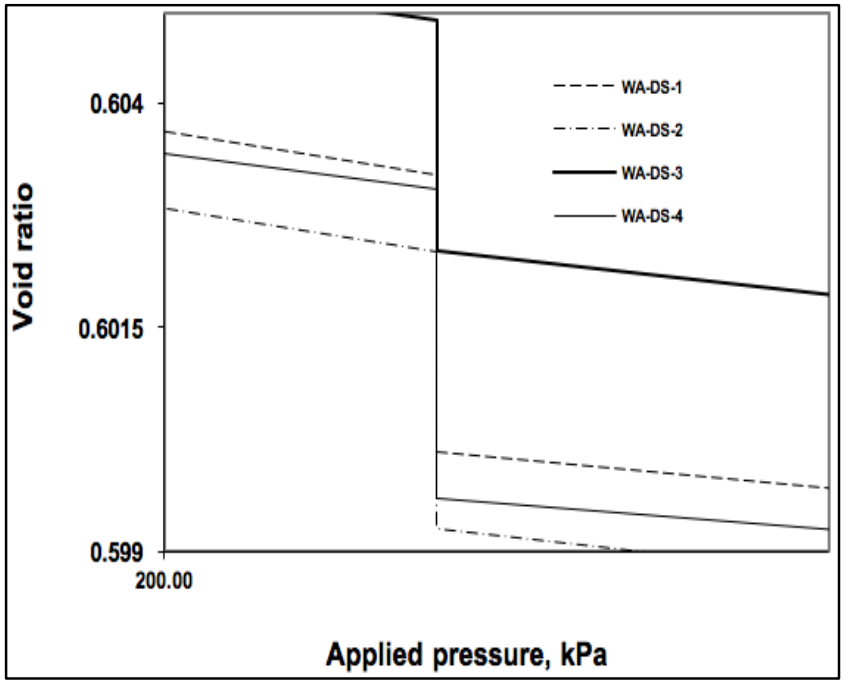

Figure 9 Collapse test results for Al-Wafra dune sand (WA-DS)

Collapse potential is calculated using the following equation:

$$
C P=\Delta e / 1+e o
$$

Where:

$\Delta \mathrm{e}$ is the difference in void ratio of the two samples at a specific stress, while $e_{o}$ is the natural void ratio.

Table 4 presents the calculated collapse potential concerning the tested soil samples.

The collapse potential of the four sabkha soil samples varies from $0.136-0.54 \%$, while the dune sand soil sample's collapse potential ranges from 0.095 $0.16 \%$.

As per [27] recommended severity rating, no problems were observed in any tested soil samples regarding slight with collapse. While the collapse potential was highest for the sabkha soil samples, it was the lowest for the dune sand soil samples, which is primarily because of their chemical composition. Because the soil composition of the dune sand is low in fine and salt content, it involves a more competent and stable matrix. Overall, the sabkha soil's cementation that the salts provide may be weakened by the moisture present in sabkha soils, which decreases the strength and increases the soil's compressibility. According to laboratory and field evidence, the fine-grained matrix causes the collapse phenomenon, and this collapse behavior can be caused by as little as $5-20 \%$ fines [43].

Table 4 The collapse potential for tested soil samples

\begin{tabular}{lc}
\hline Soil type & CP \\
\hline MA-SBK-1 & 0.1368 \\
MA-SBK-2 & 0.4526 \\
MA-SBK-3 & 0.423 \\
MA-SBK-4 & 0.168 \\
WA-SD-1 & 0.14 \\
WA-SD-2 & 0.095 \\
WA-SD-3 & 0.13 \\
WA-SD-4 & 0.15 \\
\hline
\end{tabular}

The salt bonding's dissolution as well as the capillary tension's reduction are probably the reasons for the collapse taking place following the saturation of both the sabkha and dune sand soil samples. It was noted during testing that collapse settlement did not occur immediately after saturation, but after a few hours. The slow collapse suggests chemical cement bonding, as the collapse took place because of the dissolution or softening of the bonding agents [6]. Collapse is typically regarded as caused by a loss in the binding agent's strength and then the coarse fraction's grain re-arrangement [27]. Moreover, [37] noted a lower collapse potential when studying sabkha soil, which can be caused by the sabkha soil's higher salts content in the present study. Also, [47] affirmed this in their study on the collapse of arid saline soils, and stated that that these soils need an adequate amount of water for percolating to enhance the dissolution of the cementing agents [22]. As [37] and [45] note, strong contact forces were successively carried by the grains, which crushed the soil particles because of the initial rearrangement. This may have led to more dissolution in the sabkha soil.

Similar studies conducted on arid soil by [40] showed that dune soil's collapse potential and the relative density are inversely proportional. However, lower collapsibility values are expected for the collapse potential in the soil samples tested for this study because of their maximum dry densities' compaction. Furthermore, in the case of compacted samples for modified effort, minimum axial strain is observed [40].

Overall, saturation has an important impact on the surface windblown dune sands, with collapse 
apparent at certain locations that are compacted at low relative density because of ground wetting [46]. However, it has been noted that when the coarsegrained soils present in a geologically susceptible environment are wetted, they can collapse despite having significantly high SPT blow counts and high densities [43].

\subsection{CONCLUSION}

This study examined the collapse potential of Kuwait's two major soil surface deposits: sabkha soil and dune sands. The results of the soil characterization as well as the standard front-loading oedometer tests allow us to draw several conclusions. It was noted that the sabkha soil and dune sand samples contained high levels of silicon dioxide, at $32.86 \%$ and $86.0 \%$ respectively. While the sabkha soil had higher compaction characteristics and its peaks were clearly defined, the dune sand soil had flatter compaction curves and double peaks.

Moreover, although the sabkha soil's collapse potential was higher than for dune sand, it is not regarded as a problematic soil. This may be because of its higher concentration of salts compared to those found in dune sand samples, which can result in higher collapse potential. Further studies on other sabkha locations that have higher salt content are therefore necessary.

\section{Acknowledgement}

The authors are sincerely thankful to the Public Authority for Roads \& Transportation for their support with the November 2019 soil survey and sampling. This work would have been impossible without their cooperation, as this study was self-funded and had a limited budget.

\section{References}

[1] Al-Ruwaih, F. M. 1995. Hydro geochemical Variation of Carbonate Aquifer Al Sulaibiya (South) Kuwait. Journal of Water, Air and Soil Pollution. 90: 489-505. DOI: 10.1007/BF00282664.

[2] Al-Kulaib, A. A. 1984. The Climate of Kuwait. Directorate General of Civil Aviation (DGA). Meteorological Department. 178

[3] Al-Saleh, S. and Khalaf, F. I. 1982. Surface Texture of Quartz Grains from Various Recent Sedimentary Environments in Kuwait. Journal of Sedimentary Petrology. 52(1): 215-225. DOI: 10.1306/212F7F18-2B24-11D7-8648000102C1865D.

[4] Khalaf, F. I., Gharib, I. M. and Al-Hashash, M. Z. 1984. Types and Characteristics of Recent Surface Deposits of Kuwait Arabian Gulf. Journal of Arid Environments. 7(1): 9-33. DOI: 10.1016/S0140-1963(18)31399-5.

[5] Ismael, N. F. 1984. Cement Stabilisation of Kuwait Soils. Arab Gulf Journal of Scientific Research. 2(1): 349-360.

[6] Ismael, N. F. and Mollah, M. A. 1998. Leaching Effects on Properties of Cemented Sands in Kuwait. Journal of Geotechnical and Geoenvironmental Engineering
124(10): 997-1004. DOI: 10.1061/(ASCE) 1090$0241(2000) 126: 1$ (99.2)

[7] Nayfeh, A. J. A. M. 1990. Geotechnical Characteristics of Dune Sand of Kuwait. Unpublished Master Dissertation. University of Kuwait, Kuwait.

[8] Al-Sanad, H. A., Shaqour, F. M., Hencher, S. R. and Lumsden, A. C. 1990. The Influence of Changing Groundwater Levels on the Geotechnical Behavior of Desert Sands. Quarterly Journal of Engineering Geology. 23(4): 357-364. DOI: 10.1 144/GSL.QJEG.1990.023.04.10.

[9] Al-Abdul Wahhab, H. I. and Asi, I. M. 1997. Improvement of Marl and Dune Sand for Highway Construction in Arid Areas. Building and Environment. 32(3): 271-279. DOI: 10.1016/S0360-1323(96)00067-4.

[10] Abu-Taleb, M. G. \& Egeli, I. 1981. Some Geotechnical Problems in the Eastern Province of Saudi Arabia. Proceedings Symosium on Geotechnical Problems in Saudi Arabia. 2: 799-811.

[11] Yechieli, Y. and Wood, W. W. 2002. Hydrogeologic Processes in Saline Systems: Playas, Sabkhas, and Saline Lakes. Earth-Science Reviews. 58(3-4): 343-365. DOI: 10.1016/S0012-8252(02)00067-3.

[12] Ismael, N. F., Mollah, M. A. and AL-Khaldi, O. 1986. Geotechnical Properties of Cemented Soils in Kuwait. Australian Road Research. 16(2): 94-104.

[13] Al-Otaibi, F. A. and Wegian, F. M. 2012. Investigating the Effect of Bitumen Content on Ion Dissolution in Bitumen Mixed Sabkha Soil. Kuwait Journal of Science and Engineering. 39(Issue 1B): 93-109.

[14] Aldaihani, H. M., Al-Otaibi, F. A. and Alrukaibi. D. S. 2020. Investigation of Permeability Behavior of Wet Oil Lake Contaminated Sandy Soil at Al-Ahmadi in Kuwait. International Journal of GEOMATE. 19(73): 141-147.

[15] Al-Otaibi, F. A., Wegian, F. M., Alnaki, A. A., Almutairi, S. K. H. and Singhd, R. M. 2012. Effect of Bitumen Addition on the Long-Term Permeability of Sabkha Soil. Kuwait Journal of Science and Engineering. 39(Issue 2B): 131-148.

[16] Abou-Bekr, N., Bendi-Ouis, A. and Taibi, S. 2006. Characterization of the Clay of Sikkak Core Earth Dam (West of Algeria). Proceeding of the 2006 The Fourth International Conference on Unsaturated Soils, Carefree, April 2nd -5th.: 1607-1616. Arizona, U.S.A. Edited by American Society of Civil Engineers ASCE, Geotechnica Special Publication. DOI: 10.1061/40802(189)134.

[17] Abbech E. K., Laovar M. S. and Messaoud F. 2010. Prediction of Collapsible Soils by Cone Penetrometer and Ultra Sonic Tests. Studia Geotechnica et Mechanica. 32(2): 3-21.

[18] Al-Rawas, A. A. 2000. State of the Art Review of Collapsible Soils. Journal of Science and Technology, Special Review. 5: 115-135. DOI: 10.24200/squjs.vol5iss0pp1 15-135.

[19] Das, B. M. 1983. Principals of Foundation Engineering. 7th Ed.: Thomson, Washington, U.S.A.

[20] Ali, M. M. 2011 . Identifying and Analyzing Problematic Soils. Geotechnical and Geological Engineering. 29(3): 343-350. DOI: 10.1007/s10706-010-9380-y.

[21] Al-Otaibi, F. A. 2006. An Assessment of the Possibility of Stabilization of Sabkha Soils Using Oil Lake Residue-Reuse of Waste Materials. Doctoral Thesis, Cardiff University, Wales, UK. Retrieved from: https://orca.cf.ac.uk/56046/1/U584799.pdf

[22] Rogers, C. D. F., Dijkstra, T. A. and Smallery, I. J. 1994 Keynote Lecture: Classification of Arid Soils for Engineering Purposes: An Engineering Approach. Proceedings of the 1st International Symposium 1994 on Engineering Characteristics of Arid Areas. Balkema, Rotterdam, Edited by Fookes, P.G. and Parry, R.H.G. 91-94.

[23] Rezaei, M., Ajalloeian, R. and Ghafoori, M. 2012. Geotechnical Properties of Problematic Soils Emphasis on Collapsible Cases. Int J Geosci. 3(1): 105-110. DOI: 10.4236/ijg.2012.31012

[24] Houston, S. L., Houston, W. N. and Lawrence, C. A. 2002. Collapsible Soil Engineering in Highway Infrastructure 
Development. Journal of Transportation Engineering. 128(3): 295-300. DOI: $10.1061 /($ ASCE) 0733-947X(2002)128:3(295).

[25] Ayadat, T. and Hanna, A. M. 2013. Design of Foundations Built on a Shallow Depth (Less than $4 \mathrm{~m}$ ) of Egyptian MacroPorous Collapsible Soils. Open Journal of Geology. 3(3): 209-215. DOI: 10.4236/ojg.2013.33024.

[26] Hawraa, Y. M., Al-Musawi, H. M. and Salman, A. F. 2012. Treatment of Collapsibility of Gypseous Soils by Dynamic Compaction. Geotech Geol Eng. 30(6): 1369-1387. DOI: 10.1007/s10706-012-9552-z.

[27] Mansour, Z. M., Chik, Z. and Taha, M. R. 2008. On the Procedures of Soil Collapse Potential Evaluation. Journal of Applied Science. 8(23): 4434-4439. DOI: 10.3923/jas.2008.4434.4439.

[28] Jennings, J. K. and Knight, K. 1975. The Additional Settlement of Foundation Due to Collapse of Sandy Subsoils on Wetting. Proceeding of 4th International Conference on Soil Mechanics and Foundation Engineering.

[29] Houston, S. L., Houston, W. N., and Spadola, D. J. 1988. Prediction of Field Collapse of Soils Due to Wetting. Journa of Geotechnical Engineering, ASCE. 114(1): 40-58.

[30] Knight, K. 1963. The Origin and Occurrence of Collapsing Soils. Proceedings of the Third Regional Conference for Africa 1963 on Soil Mechanics and Foundation Engineering. 127-130.

[31] Ismael, N. F. 1993. Geotechnical Characteristics of Salt Bearing Soils in Kuwait. Transportation Research Board 72nd Annual Meeting, Paper No. 930035. Washington, D. C.

[32] ASTM D2487. 2000. Standard Classification of Soils for Engineering Purposes (Unified Soil Classification System). West Conshohocken, PA, USA: American Society for Testing and Materials (ASTM) International.

[33] ASTM D422-63. 1998. Standard Test Method for Particle-Size Analysis of Soils. West Conshohocken, PA, USA: American Society for Testing and Materials (ASTM) International.

[34] ASTM D4318. 2005. Standard Test Methods for Liquid Limit, Plastic Limit, and Plasticity Index of Soils. West Conshohocken, PA, USA: American Society for Testing and Materials (ASTM) International.

[35] ASTM D854-14. 2014. Standard Test Methods for Specific Gravity of Soil Solids by Water Pycno Meter. West Conshohocken, PA, USA: American Society for Testing and Materials (ASTM) International.

[36] ASTM D1557-12. 2012. Standard Test Methods for Laboratory Compaction Characteristics of Soil Using Modified Effort (56,000 ft lbf/ft3 (2,700 kN-m/m3)). West Conshohocken, PA, USA: American Society for Testing and Materials (ASTM) International.

[37] ASTM D5333. 2003. Standard Test Method for Measurement of Collapse Potential of Soils. West Conshohocken, PA, USA: American Society for Testing and Materials (ASTM) International.

[38] Aldaihani, H. M. Z. 2017. A Geotechnical, Geochemical and Human Health Risk Assessment of a Dry Oil Lake Site in Kuwait. Doctoral Thesis. University of Portsmouth, Portsmouth, England, U.K. Retrieved from: https://researchportal.port.ac.uk/portal/en/theses/ageotechnical-geochemical-and-human-health-riskassessment-of-a-dry-oil-lake-site-in-kuwait(97d404f4-4b604a92-b82d-1a7996bb0729).html

[39] Al-Otaibi, F. A., Wegian, F. M., Alnaki, A. A., Almutairi S. K. H. and Singhd, R. M. 2012. Effect of Bitumen Addition on the Long-Term Permeability of Sabkha Soil. Kuwait J. Sci. Eng. 39: 131-148.

[40] Al-Otaibi, Fahad Abead. 2020. Variation of Sabkha Soil Permeability Associated with lonsï $\ddot{z}^{1} / 2$ Dissolution during Distilled Water Leaching. Jordan Journal of Civil Engineering. 14(2).

[41] Al-Otaibi, F. A. 2020. Dissolution Behavior of Corrosive Anions from Sabkha Soil Southern Kuwait Under Long Term Leaching. International Journal of GEOMATE. 19(74): 138144

[42] Al-Hurban, A. and Gharib, I. 2004. Geomorphological and Sedimentological Characteristics of Coastal and Inland Sabkhas, Southern Kuwait. Journal of Arid Environments. 58(1): 59-85. DOI: 10.1016/S0140-1963(03)00128-9.

[43] Al-Taie, A. J., AL-Shakarchi1, Y. J. and Mohammed, A. A. 2013. Investigation of Geotechnical Specifications of Sand Dune Soil: A Case Study Around Baiji in Iraq. IIUM Engineering Journal. 14(2): 121-132. DOI: https://doi.org/10.31436/iiumej.v14i2.408.

[44] Al-Sanad, H. A. 1986. Characterisation of Salt-Bearing Soils (Sabkha) for Pavement Design Purposes in the State of Kuwait. Journal of the University of Kuwait-Science. 13(1): 29-41.

[45] Al-Amoudi, O. S. B., Abduljauwad, S. N., El-Naggar, Z. R. and Rasheeduzzafar. 1992. Response of Sabkha to Laboratory Tests - A Case Study. Engineering Geology. 33(2): 111-125. DOI: 10.1016/0013-7952(92)90003-H.

[46] Rollins, K. M., Rollins, R. L., Smith, T. D. and Beckwith G. H. 1994. Identification and Characterization of Collapsible Gravels. Journal of Geotechnical Engineering. 120(3): 528. DOI: 10.1061/(ASCE)0733-9410(1994)120:3(528).

[47] Al-Amoudi O. S. B. and Abduljauwad S. N. 1995. Compressibility and Collapse Characteristics of Arid Saline Sabkha Soils. Engineering Geology. 39(3-4): 185-202. DOI: 10.1016/0013-7952(95)00016-9.

[48] Al-Otaibi, F. A. and Aldaihani, H. M. 2018. Influence of Bitumen Addition on Sabkha Shear Strength Characteristics Under Dry and Soaked Conditions. American Journal of Engineering and Applied Science. 11(4): 1199-1209. DOI: 10.3844/ajeassp.2018.1199.1208.

[49] Ismael, N. F. 2019. Properties and Behavior of Arid Climate Soil Deposits in Kuwait. Project from Civil Engineering Department, Kuwait University retrieved on 5 April 2019 from http://eprints.kfupm.edu.sa/1798/1/343384_PROPERTIES_AND_BEHAVIOR_OF_ARID_CLIMATE_SOIL_ DEPOSITS_IN_KUWAIT_Nabil_F_Ismael_Kuwait_University.PD F.

[50] Al-Amoudi, O. S. B. and Abduljauwad, S. N. 1995. Compressibility and Collapse Characteristics of Arid Saline Sabkha Soils. Engineering Geology. 39(3-4): 185-202. DOI: 10.1016/0013-7952(95)00016-9. 